\title{
PENGENDALIAN PERSEDIAAN TEH DENGAN MEMPERTIMBANGKAN KENDALA BIAYA PERSEDIAAN DAN KAPASITAS GUDANG
}

\author{
Olaviane Anaros Octavia Nainggolan', Theresia Sunarni ${ }^{2}$ \\ 1,2 Program Studi Teknik Industri, Fakultas Sains dan Teknologi, \\ Universitas Katolik Musi Charitas \\ Jl. Bangau No. 60 Palembang 30113. Telp (0711)366326 \\ Pos-el: olavianeaon@gmail.com, nani_vs@yahoo.com
}

\begin{abstract}
Inventory control is an important issue which must be considered by every company. The occurrence of overstock or excess inventories led to an increase in inventory cost the same as if the stockout. PT Perkebunan Nusantara VII Distrik Banyuasin is a company engaged in agriculture and processing of agricultural products such as palm oil, tea and rubber. Products covered is controlling tea products in the warehouse because of the problems that often occur in tea products. Kinds of tea products discussed namely BOP, BOPF, PF, DUST, BP, BT, PF II, DUST II, BP II, BT II, DUST III, FANN II, DUST IV. PT Perkebunan Nusantara VII Distrik Banyuasin has re- ordering method is less precise so that the reorder point should be calculated. To determine the fluctuating demand in the next year with forecasting is carried WinQsb program based on the pattern of sales data. Pattern sales data for 33 months is a seasonal pattern. The total cost incurred by the company during this time with a reservation made is Rp 385506418 , - . Therefore, we need a method that can control the supply so as to meet the demand for timely and can reduce the total cost of inventory. The method used is Multi Item EOQ method that produces a total cost of inventory Rp 414195905 ,-. Because the total cost of inventory with EOQ method Multi Item is greater than the method used by the company that carried out the study with Lagrange method taking into account capacity constraints warehouse and inventory costs which resulted in a total cost of inventories Rp 257 524800 ,- which is smaller than the methods of the company . With the Lagrange method can save a total inventory cost Rp 127981619 , - with a percentage of 33.2 $\%$.
\end{abstract}

Keywords: Control, EOQ Multi Item, Lagrange, Total cost

\section{PENDAHULUAN}

Perusahaan saat ini harus mampu bersaing untuk menjadi yang terbaik dari antara perusahaan lainnya. Dalam mencapainya perusahaan harus melakukan setiap proses produksi, manajemen, dan yang lainnya dengan sebaik-baiknya sehingga output yang dihasilkan perusahaan tersebut baik pula. Manajemen yang harus dilakukan salah satunya yaitu manajemen persediaan baik persediaan bahan baku, barang setengah jadi, dan barang jadi. Manajemen persediaan perlu dilakukan dengan tujuan untuk memenuhi kebutuhan konsumen yang tidak pasti sehingga perusahaan tidak kehilangan kesempatan untuk mendapatkan keuntungan karena tidak memiliki persediaan barang jadi di saat permintaan meningkat. Semakin bertambahnya jumlah penduduk maka semakin bertambah pula kebutuhan yang 
harus dipenuhi seperti sandang, pangan, dan papan. Salah satu kebutuhan pangan yang banyak kegunaannya adalah teh. PT Perkebunan Nusantara VII Distrik Banyuasin memproduksi teh dengan banyak jenis. Salah satunya dengan cara menentukan safety stock pada gudang-gudang tersebut. Safety stock yang tidak sesuai dapat mengakibatkan kerugian. Jika persediaan di gudang mengalami overstock akan mengakibatkan penambahan biaya persediaan sedangkan jika gudang mengalami stockout akan mengakibatkan perusahaan akan kehilangan kesempatan untuk mendapatkan pemasukan dari konsumen.

Biaya pengeluaran yang digunakan gudang sebesar Rp 35.000.000,-. Cukup tinggi mencapai 15\% dari keseluruhan biaya untuk teh pada bulan Januari 2016 hingga September 2016 yaitu Rp 233.545.325,-. Metode Lagrange adalah metode optimasi dengan pembatas dan penyelesaian satu atau dua kendala. Metode ini dapat digunakan dalam pengendalian banyak produk. Kendala dari pergudangan tersebut adalah biaya persediaan yang dikeluarkan serta kapasitas gudang yang tersedia sehingga metode Lagrange ini dapat menyelesaikan masalah tersebut. Dari latar belakang tersebut dapat dirumusan masalah bagaimana mendapatkan jumlah pengiriman optimal dan mendapatkan safety stock yang sesuai sehingga dapat meminimasi biaya persediaan teh dengan kendala kapasitas dan biaya persediaan di gudang PT Perkebunan Nusantara VII Distrik Banyuasin. Dilakukannya penelitian ini bertujuan untuk yang pertama mendapatkan jumlah safety stock teh yang harus disimpan di gudang PT Perkebunan Nusantara VII Distrik Banyuasin untuk menghadapi permintaan yang berfluktuasi, kedua mengetahui jumlah pemesanan teh dari pabrik, dan ketiga meminimasi biaya persediaan di gudang teh PT Perkebunan Nusantara VII Distrik Banyuasin.

Penelitian ini dilakukan dengan menggunakan data permintaan didapatkan berdasarkan peramalan data penjualan selama 33 bulan. Penelitian yang dilakukan di PT Perkebunan Nusantara VII Distrik Banyuasin ini hanya membahas produk teh. Penelitian yang terkait dengan penelitian ini adalah penelitian yang dilakukan oleh [1] dengan judul Pengendalian Persediaan Suplemen Kesehatan Dengan Metode Economic Order Quantity (EOQ) Multi Item Di Stokis 339. Penelitian tersebut hanya menggunakan metode EOQ sedangkan penelitian yang akan dilakukan melanjutkan penelitian dengan metode lagrange. Penelitian yang terkait lainnya yaitu penelitian yang dilakukan oleh [2] dengan judul Sistem Persediaan Multi Item Dengan Kendala Investasi dan Luas Gudang. Perbedaan dengan peneliti ini adalah peneliti ini membandingkan metode Lagrange dengan metode LIMIT sedangkan penelitian yang dilakukan membandingkan dengan metode perusahaan.

\section{METODE}

Penelitian ini dilakukan dengan studi pendahuluan yang dilakukan dengan studi lapangan di PT Perkebunan Nusantara VII Distrik Banyuasin. Studi lapangan yang dilakukan adalah observasi dan melakukan wawancara terhadap pekerja. Selanjutnya melakukan studi pustaka untuk mencari metode serta literatur seperti buku, jurnal, peneliti terdahulu dan yang lainnya. Setelah diketahui masalah yang ada selanjutnya dilakukan perumusan masalah sesuai dengan hasil studi pendahuluan yang dilakukan. Dengan rumusan masalah yang ada dapat dibuat tujuan dari penelitian yang akan dilakukan untuk mengetahui arah penelitian. Langkah selanjutnya yaitu pengumpulkan data-data yang dibutuhkan seperti data penjualan 


\section{Jurnal TEKNO}

(Civil Engineeering, Elektrical Engineeering and Industrial Engineeering)

Vol. 16, No : 1, April 2019 , p-ISSN:1907-5243, e-ISSN: 2655-8416

teh selama 13 bulan, data harga teh, data biaya pemesanan, data biaya simpan, serta data gambaran perusahaan. Setelah mendapatkan data maka dilakukanlah pengolahan data sesuai dengan metode yang digunakan dalam penyelesaian masalah. Data biaya-biaya untuk menghitung jumlah biaya yang digunakan. Data penjualan teh dilakukan peramalan secara agregat untuk 12 bulan selanjutnya dengan menggunakan program WinQsb. Setelah itu dihitung total biaya yang digunakan perusahaan. Selanjutnya dihitung pemesanan optimum menggunaka metode Economic Order Quantity (EOQ) serta menghitung biaya persediaan. Setelah mendapatkan total biaya lalu membandingkan metode perusahaan dengan metode EOQ. Jika biaya dengan metode EOQ lebih besar maka langkah selanjutnya menghitung pemesanan optimum menggunakan metode Lagrange serta menghitung biaya persediaan. setelah itu membandingkan total biaya metode perusahaan dengan metode Lagrange. Dari pengolahan data yang telah dihitung selanjutnya dilakukan analisis hasil dari pengolahan data tersebut berdasarkan tujuan yang telah dibuat.

\subsection{Persediaan}

Persediaan merupakan suatu model yang umum digunakan untuk menyelesaikan masalah yang terkait dengan usaha pengendalian bahan baku maupun barang jadi dalam suatu aktifitas perusahaan. Ciri khas dari model persediaan adalah optimalnya difokuskan untuk menjamin persediaan dengan biaya yang serendah rendahnya [3]

Inventory atau persediaan adalah suatu teknik untuk manajemen material yang berkaitan dengan persediaan. Manajemen material dalam inventory dilakukan dengan beberapa input yang digunakan yaitu: permintaan yang terjadi (demand), dan biayabiaya yang terkait dengan penyimpanan, serta biaya apabila terjadi kekurangan persediaan (short-age).

Fungsi utama persediaan yaitu sebagai penyangga, penghubung antar proses produksi dan distribusi untuk memperoleh efisiensi [4] mendefinisikan bahwa persediaan memiliki tiga fungsi, yaitu:

a. Fungsi Decoupling

Fungsi decoupling adalah fungsi persediaan yang memungkinkan perusahaan dapat memenuhi permintaan pelanggan tanpa tergantung kepada pemasok.

b. Fungsi Economic Lot Sizing

Fungsi Economic Lot Sizing adalah fungsi persediaan yang perlu mempertimbangkan penghematan atau potongan pembelian, biaya pengangkutan per unit menjadi lebih murah dan sebagainya.

c. Fungsi Antisipasi

Fungsi antisipasi adalah fungsi persediaan dalam menghadapi fluktuasi permintaan yang dapat diperkirakan dan diramalkan berdasarkan pengalaman atau data-data masa lalu, yaitu permintaan musiman.

Persediaan merupakan salah satu pos modal kerja yang cukup penting karena kebanyakan modal usaha perusahaan adalah dari persediaan. Pada perusahaan dagang, persediaan tersebut merupakan barang dagangan, sedangkan pada perusahaan industri, persediaan tersebut dapat berupa bahan mentah (row material), barang dalam proses (work in process), maupun barang jadi (finished good).

Kekurangan atau kelebihan persediaan merupakan gejala yang kurang baik. Kekurangan dapat berakibat larinya pelanggan sedangkan kelebihan persediaan dapat berakibat pemborosan atau tidak efisien. Oleh karena itu manajemen 


\section{Jurnal TEKNO}

(Civil Engineeering, Elektrical Engineeering and Industrial Engineeering)

Vol. 16, No : 1, April 2019 , p-ISSN:1907-5243, e-ISSN: 2655-8416

persediaan berusaha agar jumlah persediaan yang ada dapat menjamin kelancaran proses produksi. Dengan kata lain, total cost yang berhubungan dengan persediaan dapat minimal. Perhitungan total cost dari persediaan secara keseluruhan dipengaruhi oleh faktor-faktor pembentuk biaya dari persediaan seperti, Holding cost atau carrying cost, ordering cost atau set-up cost, serta stock, out cost [5]

1. Holding cost atau carrying cost

Adalah biaya yang timbul karena perusahaan menyimpan persediaan.

2. Ordering cost atau set-up cost

Adalah biaya yang berhubungan dengan pemesanan dan pengadaan bahan.

3. Stock out cost

Adalah biaya yang timbul akibat perusahaan kehabisan persediaan.

Untuk pengambilan keputusan penetuan besarnya jumlah persediaan, biaya-biaya variabel ini harus dipertimbangkan [5] :

1. Biaya penyimpanan (Holding costs atau carrying costs), yaitu terdiri atas biaya-biaya yang bervariasi secara langsung dengan kuantitas persediaan. Biaya penyimpanan per periode akan semakin besar apabila kuantitas bahan yang dipesan semakin banyak atau rata-rata persediaan semakin tinggi. Biaya-biaya yang termasuk sebagai biaya penyimpanan adalah:

2. Biaya pemesanan atau pembelian (ordering costs atau procurement costs).

3. Biaya penyiapan (manufacturing) atau set-up cost

4. Biaya kehabisan atau kekurangan bahan (shortage costs)

\subsection{Penentuan Safety Stock (SS) dan Reorder Point (ROP)}

Berikut rumus untuk menghitung besarnya safety stock:

$$
S S=z \times S
$$

Keterangan:

SS = Besarnya Safety Stock

$\mathrm{S} \quad=$ Nilai Standar Deviasi dari Permintaan

$\mathrm{z}=$ service level value

$$
\left(S=\sqrt{\frac{\sum(\bar{x}-x)^{2}}{n}}\right)
$$

Sedangkan, untuk menentukan kapan saat dimana perlu dilakukan pemesanan ulang disebut Reorder Point (ROP), yang didapatkan dari:

$$
\mathrm{ROP}=\mathrm{SS}+(1 \times \mathrm{D})
$$

Keterangan:

$\mathrm{ROP}=$ Titik dimana perlu dilakukan pemesanan dengan kuantitas optimal, sehingga kebutuhan saat lead time tetap terpenuhi

$\mathrm{SS}=$ Besarnya safety stock

1 = Lamanya lead time produk

$\mathrm{D}=$ Kebutuhan per hari.

\subsection{Model Economic Order Quantity (EOQ) untuk Multi Item}

Rumus EOQ optimal (dalam rupiah) adalah sebagai berikut,

$$
Q_{S}^{*}=\sqrt{\frac{2 \times\left(\mathrm{S}+\sum S i\right) \mathrm{A}}{\mathrm{k}}}
$$




\section{Jurnal TEKNO}

(Civil Engineeering, Elektrical Engineeering and Industrial Engineeering)

Vol. 16, No : 1, April 2019 , p-ISSN:1907-5243, e-ISSN: 2655-8416

Selanjutnya rumus EOQ (dalam rupiah) untuk masing-masing item adalah sebagai berikut

$$
Q_{s i}^{*}=\left(\frac{a_{i}}{\mathrm{~A}}\right) Q_{s}{ }^{*}
$$

Sedangkan nilai EOQ untuk masing-masing item (dalam unit)

$$
Q_{s}{ }^{*}=\frac{Q_{s i}{ }^{*}}{C_{i}}
$$

Untuk menghitung total biaya perseediaan atau total cost (TC), sebagai berikut

$$
\mathrm{TC}=\frac{S \cdot R}{Q}+\frac{Q \cdot(k \cdot C)}{2}
$$

Untuk menghitung ekspektasi banyaknya pemesanan selama satu tahun, sebagai berikut [5]:

$\mathrm{m}=\frac{R}{Q}$

Keterangan:

$S=$ biaya pemesanan yang tidak tergantung jumlah item pada setiap kali pesan,

$S_{i}=$ biaya pemesanan tambahan karena adanya penambahan item ke-i dalam pesanan,

$\mathrm{k}=$ biaya simpan $(\%)$,

$\mathrm{Q}=$ jumlah pemesanan yang ekonomis untuk satu kali pesan (unit),

$\mathrm{C}=$ harga beli produk per unit (Rp),

$\mathrm{R}=$ jumlah kebutuhan produk per tahun,

$a_{i}=$ biaya pembelian yang diperlukan selama periode tertentu untuk item $i$ (dalam rupiah),

$A=$ jumlah biaya pembelian yang diperlukan selama periode perencanaan untuk semua jenis item (dalam rupiah),

$C_{i}=$ harga beli per unit item ke-i (satuannya rupiah/unit),

$\mathrm{m}=$ kuantitas pemesanan per tahun.

\subsection{Metode Lagrange}

Permasalahan ini diformulasikan melalui model optimasi dengan pembatas dan penyelesaiannya menggunakan metode Lagrange. Dalam penerapannya metode ini hanya mengacu kepada satu atau dua kendala [6] :

$$
\sum_{i=1}^{n} C_{i} Q_{i} \leq B
$$

dengan

$\mathrm{C}_{\mathrm{i}}=$ harga satuan unit item produk i dalam rupiah

$\mathrm{Q}_{\mathrm{i}}=$ kuantitas pesanan optimal item produk i dalam unit

$\mathrm{B}=$ besarnya investasi dalam persediaan dalam rupiah

Jika $\mathrm{n}$ adalah jumlah item, maka tujuan dari penyelesaian permasalahan ini adalah untuk meminimisasi total biaya persediaan per periode. Sebagai langkah awal maka perlu dicari kuantitas pemesanan paling optimal dengan mengabaikan adanya konstrain atau kendala, sehingga untuk mendapatkan nilai Qi* digunakan formulasi:

$$
\mathrm{Q}_{\mathrm{i}}^{*}=\sqrt{\frac{2 A_{i} D_{i}}{a C_{i}}}
$$

Dari perhitungan melalui persamaan (10), cek kondisinya dengan mensubstitusikan nilai Qi* pada persamaan (9). Apabila nilai Qi* belum memuaskan, 


\section{Jurnal TEKNO}

\section{(Civil Engineeering, Elektrical Engineeering and Industrial Engineeering) \\ Vol. 16, No : 1, April 2019 , p-ISSN:1907-5243, e-ISSN: 2655-8416}

maka metode Lagrange mulai digunakan. Permasalahan ini dapat diselesaikan dengan mengembangkan Lagrange Expression (LE) atau persamaan Lagrange, yakni:

$$
\mathrm{LE}\left(\mathrm{Q}_{\mathrm{i}}, \lambda\right)=\sum_{i=1}^{n}\left(\frac{A_{i} D_{i}}{Q_{I}}+\frac{a}{2} C_{i} Q_{I}\right)+\lambda\left(\sum_{i=1}^{n} C_{i} Q_{I}-B\right) .
$$

Notasi $\lambda$ adalah faktor pengali Lagrange. Dengan mengambil turunan atau derivatif dari persamaan (11) yang dikondisikan pada nilai $\mathrm{Qi}, \lambda$, dan menyelesaikan persamaan tersebut dengan ruas kanan disamadengankan nol, maka diperoleh formulasi:

$\mathrm{Q}_{\mathrm{L}_{\mathrm{i}}}^{*}=\sqrt{\frac{2 \mathrm{~A}_{\mathrm{i}} \mathrm{D}_{\mathrm{i}}}{\mathrm{C}_{\mathrm{i}}\left(\mathrm{a}+2 \lambda^{*}\right)}}$

nilai $\mathrm{Q}^{*} \mathrm{Li}$ adalah kuantitas pemesanan optimal yang diperoleh dari penggunaan

metode Lagrange. Harga dari $\lambda^{*}$ dapat diperoleh dengan formulasi:

$$
\lambda^{*}=\frac{1}{2}\left(\frac{1}{\mathrm{~B}} \sum \sqrt{2 \mathrm{~A}_{\mathrm{i}} \mathrm{D}_{\mathrm{i}} \mathrm{C}_{\mathrm{i}}}\right)^{2}
$$

kemudian mensubstitusikannya ke persamaan (12) dan akan memberikan persamaan:

$$
\mathrm{Q}_{\mathrm{L}_{\mathrm{i}}}^{*}=\frac{\mathrm{B}}{\sum_{\mathrm{i}=1}^{\mathrm{n}} \mathrm{C}_{\mathrm{i}} \mathrm{Q}_{\mathrm{i}}^{*}} \mathrm{Q}_{\mathrm{i}}^{*}=\frac{\mathrm{B}}{\mathrm{E}} \mathrm{Q}_{\mathrm{i}}^{*}
$$

Untuk $\mathrm{Q}_{\mathrm{i}}^{*}$ dicari dengan persamaan (10) dan $\mathrm{E}$ dicari dengan persamaan:

$$
\mathrm{E}=\sum_{i=1}^{n} C_{i} Q_{i}^{*}
$$

sedangkan untuk kendala ruang penyimpanan, total ruang penyimpanan dihitung dengan formulasi:

$$
\sum_{i=1}^{n} F_{i} Q_{L_{i}}^{*} \leq S-S_{a}
$$

Selanjutnya, untuk mencari total investasi dari perhitungan Lagrange dikondisikan pada total investasi dari kebijakan perusahaan dan dapat dicari dengan formulasi:

$$
\sum_{i=1}^{n} C_{i} Q_{L_{i}}^{*} \leq B
$$

\section{keterangan:}

$\mathrm{C}_{\mathrm{i}} \quad=$ harga item per unit dalam rupiah

$\mathrm{A}_{\mathrm{i}} \quad$ = biaya pengadaan atau pemesanan per item dalam rupiah

$\mathrm{D}_{\mathrm{i}}=$ permintaan hasil peramalan dalam unit

$\mathrm{B}=$ investasi maksimum yang diijinkan di perusahaan dalam rupiah

$\mathrm{E}=$ total investasi persediaan tanpa konstrain dalam rupiah

$\mathrm{Q}_{\mathrm{i}}^{*} \quad=$ kuantitas pemesanan optimal tanpa konstrain dalam unit

$\mathrm{Q}_{\mathrm{Li}}^{*}=$ kuantitas pemesanan optimal dengan Lagrange dalam unit

$\mathrm{Q}_{\mathrm{i}}=$ kuantitas pemesanan hasil peramalan dalam unit

$\lambda^{*}=$ faktor pengali Lagrange

$\mathrm{a}=$ biaya penyimpanan inventori dalam persentase

$\mathrm{S}=$ kapasitas gudang

$\mathrm{S}_{\mathrm{a}}=$ kapasitas persediaan akhir

\section{HASIL DAN PEMBAHASAN}

PT Perkebunan Nusantara VII Distrik Banyuasin terletak di Jalan Kolonel H. Burlian Km. 9,5. Visi PT Perkebunan Nusantara VII adalah menjadi perusahaan agribisnis berbasis karet, kelapa sawit, teh dan tebu yang tangguh, serta berkarakter global. Misi PT Perkebunan Nusantara VII Distrik Banyuasin adalah untuk menjalankan usaha perkebunan, mengembangkan usaha industri yang terintegrasi, mengebangkan sumber daya manusia, membangun tata kelola usaha yang efektif, dan memelihara 


\section{Jurnal TEKNO}

(Civil Engineeering, Elektrical Engineeering and Industrial Engineeering)

Vol. 16, No : 1, April 2019 , p-ISSN:1907-5243, e-ISSN: 2655-8416

keseimbangan kepentingan stakeholder. Data yang dibutuhkan adalah data penjualan teh selama 33 bulan..

Data penjualan teh yang telah dikumpulkan dilakukan pengolahan data untuk mendapatkan ramalan jumlah teh 12 bulan selanjutnya. Data diramalkan menggunakan program WinQsb. Metode yang digunakan untuk meramalkan data adalah metode HoltWinters Additive Algorithm (HWA) dan metode Holt-Winters Multipcative Algorithm (HWM). Metode tersebut dipilih karena data penjualan teh membentuk pola musiman. [7] Setelah dihitung, dapat dilihat nilai MAD yang terkecil akan dipilih metode tersebut sehingga terpilihlah metode Holt-Winters Multipcative Algorithm. Setelah itu, dihitunglah biaya-biaya yang digunakan yaitu biaya pembelian, pemesanan, dan biaya simpan. Biaya pembelian sebesar Rp 47.903.786.474, biaya pemesanan sebesar Rp 374.610,- yang didapatkan dari biaya listrik, biaya internet, biaya tenaga kerja, biaya telepon, dan biaya transportasi, serta biaya simpan sebesar $20 \%$ dari harga barang yang disimpan.

a. Rata-rata peramalan jenis BOP selama 12 periode ke depan

$$
\begin{aligned}
\bar{X} & =\frac{\text { Total Penggunaan BOP }}{12 \text { bulan }} \\
& =\frac{2973,1}{12 \text { bulan }} \\
& =247,75
\end{aligned}
$$

b. Standar Deviasi

$$
\begin{aligned}
S & =\sqrt{\frac{\sum(x-\bar{x})^{2}}{12}} \\
& =\sqrt{\frac{(261,2-247,75)^{2}+(258,8-247,75)^{2}+\ldots+(234,2-247,75)^{2}}{12}} \\
& =8,81
\end{aligned}
$$

c. Penentuan nilai $Z$

Service Level $=80 \%$. maka nilai $Z=0,84$

d. Besarnya Safety Stock (SS)

$$
\begin{aligned}
\text { Safety Stock } & =\mathrm{Z} \times \text { Standar Deviasi } \\
& =0,84 \times 8,81 \\
& =7,4 \approx 8
\end{aligned}
$$

ROP jenis BOP

$$
\begin{aligned}
\text { ROP } & =S S+(D \times l) \\
\text { ROP } & =7,4+(9,9 \times 2) \\
& =27,22
\end{aligned}
$$

\subsection{Perhitungan dengan Metode EOQ Jenis BOP}

$$
\begin{aligned}
Q_{s}^{*} & =\sqrt{\frac{2 \times\left(\mathrm{S}+\sum S i\right) \mathrm{A}}{\mathrm{k}}} \\
& =\sqrt{\frac{2 \times(374.610) \times 47.903 .786 .474}{20 \%}} \\
& =\operatorname{Rp} 423.618 .194,- \\
Q_{s i}{ }^{*} & =\left(\frac{a_{i}}{\mathrm{~A}}\right) Q_{s}{ }^{*} \\
& =\left(\frac{5.160 .790 .892}{47.093 .786 .474}\right) \times 423.618 .194 \\
& =\operatorname{Rp} 45.637 .414,-
\end{aligned}
$$




\section{Jurnal TEKNO}

(Civil Engineeering, Elektrical Engineeering and Industrial Engineeering)

Vol. 16, No : 1, April 2019 , p-ISSN:1907-5243, e-ISSN: 2655-8416

$$
\begin{aligned}
Q_{s}{ }^{*} & =\frac{Q_{s i}{ }^{*}}{C_{i}} \\
& =45.637 .414 / 1.172 .028 \\
& =39 / \text { sack }
\end{aligned}
$$

Sehingga banyaknya pemesanan teh dilakukan selama 12 bulan ke depan adalah sebagai berikut:

$\mathrm{m}=\frac{2973,1}{39}=77 \mathrm{kali}$

Jadi pemesanan akan dilakukan 77 kali selama 12 bulan ke depan.

Total Biaya Persediaan Jenis BOP

$$
\begin{aligned}
\mathrm{TC} & =\frac{S . R}{Q}+\frac{Q \cdot(k . C)}{2} \\
& =\frac{R p 374.610 \times 2973,1}{39}+\frac{39(0,2 \times R p 1.172 .028)}{2} \\
& =\operatorname{Rp} 33.166 .363,-
\end{aligned}
$$

Tabel 1 berikut menunjukkan rekapitulasi perhitungan safety stock, reorder point, Q, dan total cost dengan metode EOQ.

Tabel 1. Rekapitulasi Safety Stock, Reorder Point, dan Perhitungan Dengan Metode EOQ

\begin{tabular}{|c|c|c|c|c|c|c|c|c|}
\hline No. & Jenis & $\overline{\mathbf{X}}$ & $\mathbf{S S}$ & $\mathbf{R O P}$ & $\boldsymbol{Q}_{s}{ }^{*}(\mathbf{R p})$ & $\boldsymbol{Q}_{\boldsymbol{s i}}{ }^{*}(\mathbf{R p})$ & $\begin{array}{c}\mathbf{Q}_{\boldsymbol{s}}{ }^{*} \\
(\text { Sack })\end{array}$ & $\mathbf{T C}(\mathbf{R p})$ \\
\hline 1. & BOP & 247,75 & 8 & 27,22 & 423.618 .194 & 45.637 .414 & 39 & 33.166 .363 \\
\hline 2. & BOPF & 371,63 & 12 & 40,84 & 423.618 .194 & 63.828 .551 & 58 & 34.985 .477 \\
\hline 3. & PF & 371,63 & 12 & 40,84 & 423.618 .194 & 73.721 .976 & 58 & 35.974 .819 \\
\hline 4. & DUST & 22,98 & 7 & 24,5 & 423.618 .194 & 50.763 .498 & 35 & 33.678 .971 \\
\hline 5. & BP & 24,77 & 1 & 2,72 & 423.618 .194 & 4.521 .189 & 4 & 29.054 .740 \\
\hline 6. & BT & 445,96 & 14 & 49,01 & 423.618 .194 & 53.231 .890 & 70 & 33.925 .810 \\
\hline 7. & PF II & 173,43 & 6 & 19,05 & 423.618 .194 & 31.483 .581 & 27 & 31.750 .980 \\
\hline 8. & DUST II & 123,87 & 4 & 13,61 & 423.618 .194 & 26.275 .834 & 19 & 31.230 .205 \\
\hline 9. & BP II & 24,77 & 1 & 2,72 & 423.618 .194 & 4.237 .659 & 4 & 29.026 .387 \\
\hline 10. & BT II & 123,87 & 4 & 13,61 & 423.618 .194 & 18.113 .629 & 19 & 30.413 .984 \\
\hline 11. & DUST III & 49,55 & 2 & 5,44 & 423.618 .194 & 9.550 .670 & 8 & 29.557 .688 \\
\hline 12. & FANN II & 247,75 & 8 & 27,22 & 423.618 .194 & 32.869 .834 & 39 & 31.889 .605 \\
\hline 13. & DUST IV & 49,55 & 2 & 5,44 & 423.618 .194 & 9.382 .469 & 8 & 29.540 .868 \\
\hline
\end{tabular}

\subsection{Perhitungan dengan Metode Lagrange}

Berikut adalah contoh perhitungan Q tanpa kendala jenis BOP

$$
\begin{aligned}
\mathrm{Q} & =\sqrt{\frac{2 A i D i}{\mathrm{aCi}}} \\
& =\sqrt{\frac{2 \times 374.610 \times 2973,1}{0,2 \times 1.172 .028}} \\
& =97 \mathrm{sack}
\end{aligned}
$$

Berikut adalah rumus metode lagrange dan perhitungan faktor pengali lagrange.

$$
\begin{aligned}
& \mathrm{LE}(\mathrm{Qi} . \lambda)=\sum_{i=1}^{n}\left(\frac{374.610 \times D i}{Q i}+\frac{0.2}{2} 1.172 .028 \times Q i\right)+\lambda(-136.154 .718) \lambda= \\
& \begin{aligned}
\frac{1}{2}\left(\frac{1}{\mathrm{~B}} \sum \sqrt{2 \mathrm{~A}_{\mathrm{i}} \mathrm{D}_{\mathrm{i}} \mathrm{C}_{\mathrm{i}}}\right)^{2}-\frac{\mathrm{a}}{2} \\
=\frac{1}{2}\left(\frac{1}{1.300 .000 .000} 368.040 .193 .4\right)^{2}-\frac{0.2}{2} \\
=-0.06
\end{aligned}
\end{aligned}
$$

Berikut adalah contoh perhitungan Q dengan kendala jenis BOP. 


\section{Jurnal TEKNO}

(Civil Engineeering, Elektrical Engineeering and Industrial Engineeering)

Vol. 16, No : 1, April 2019 , p-ISSN:1907-5243, e-ISSN: 2655-8416

$$
\begin{aligned}
\mathrm{Q}_{\mathrm{L}_{\mathrm{i}}}^{*} & =\sqrt{\frac{2 \mathrm{~A}_{\mathrm{i}} \mathrm{D}_{\mathrm{i}}}{\mathrm{C}_{\mathrm{i}}\left(\mathrm{a}+2 \lambda^{*}\right)}} \\
& =\sqrt{\frac{2 \times 374.610 \times 2973.1}{1.172 .028(0.2+2(-0.06)}} \\
& =154 \text { sack }
\end{aligned}
$$

Total Biaya Persediaan Jenis BOP

$\mathrm{TC}=\frac{S \cdot R}{Q}+\frac{Q \cdot(k \cdot C)}{2}$

$=\frac{R p 374.610 \times 2973,1}{154}+\frac{154(0,2 \times R p 1.172 .028)}{2}$
$=\operatorname{Rp} 25.280 .592,-$

Rekapitulasi hasil perhitungan dengan metode lagrange dapat dilihat pada Tabel 2 berikut ini:

Tabel 2. Rekapitulasi Perhitungan Dengan Metode Perusahaan dan Metode Lagrange

\begin{tabular}{|c|c|c|c|c|c|c|}
\hline No & Jenis & $\begin{array}{c}\text { Q } \\
\text { Perusahaan } \\
(\text { sack })\end{array}$ & $\begin{array}{c}\text { TC } \\
\text { Perusahaan } \\
(\mathbf{R p})\end{array}$ & $\begin{array}{c}\text { Q tanpa } \\
\text { kendala } \\
(\text { sack })\end{array}$ & $\begin{array}{c}\text { Q } \\
\text { dengan } \\
\text { kendala } \\
(\text { sack })\end{array}$ & $\begin{array}{c}\text { TC lagrange } \\
(\mathbf{R p})\end{array}$ \\
\hline 1. & BOP & 40 & 32.531 .936 & 97 & 154 & 25.280 .592 \\
\hline 2. & BOPF & 59 & 34.763 .274 & 124 & 195 & 29.897 .455 \\
\hline 3. & PF & 58 & 36.124 .623 & 115 & 182 & 32.131 .072 \\
\hline 4. & DUST & 37 & 32.405 .831 & 83 & 131 & 26.662 .600 \\
\hline 5. & BP & 5 & 22.855 .609 & 31 & 49 & 7.957 .068 \\
\hline 6. & BT & 72 & 33.312 .080 & 162 & 257 & 27.303 .145 \\
\hline 7. & PF II & 28 & 31.077 .981 & 82 & 130 & 20.997 .558 \\
\hline 8. & DUST II & 20 & 30.543 .014 & 64 & 101 & 19.182 .490 \\
\hline 9. & BP II & 5 & 22.819 .202 & 32 & 51 & 7.703 .530 \\
\hline 10. & BT II & 21 & 28.471 .690 & 77 & 122 & 15.926 .834 \\
\hline 11. & DUST III & 10 & 23.501 .427 & 43 & 67 & 11.564 .947 \\
\hline 12. & FANN II & 40 & 31.220 .384 & 115 & 181 & 21.454 .850 \\
\hline 13. & DUST IV & 9 & 25.834 .359 & 43 & 68 & 11.462 .658 \\
\hline
\end{tabular}

Total biaya dengan metode Lagrange adalah sebesar Rp 257.524.800,- sedangkan total biaya dengan metode perusahaan sebesar Rp 385.506.418,-- Pengurangan biaya yang terjadi adalah sebesar Rp 127.981.619,- dengan persentase sebesar 33,2\%. Tabel perbandingan total biaya persediaan dari ketiga metode dapat dilihat pada Tabel 3.

Tabel 3 Perbandingan Total Biaya Persediaan

\begin{tabular}{|c|c|c|}
\hline No & Metode & Total Biaya Persediaan (Rp) \\
\hline 1 & Perusahaan & 385.506 .418 \\
\hline 2 & EOQ Multi Item & 414.195 .905 \\
\hline 3 & Lagrange & 257.524 .800 \\
\hline
\end{tabular}

\subsection{Analisis Metode yang Digunakan Perusahaan dan Metode EOQ Multi Item}

Pemesanan teh ke pabrik dilakukan setiap 3 hari sekali sehingga lead time pemesanan adalah 2 hari. Selama ini perusahaan tidak menetapkan besarnya safety stock serta besarnya pemesanan produk dari pabrik sehingga produk yang ada di gudang tidak menentu. Pemesanan produk dilakukan sesuai dengan keadaan jadi tidak semua produk dikirim dalam satu kali pemesanan. Total biaya persediaan dengan metode yang digunakan perusahaan adalah sebesar Rp 385.506.418,-. 


\section{Jurnal TEKNO}

\section{(Civil Engineeering, Elektrical Engineeering and Industrial Engineeering) \\ Vol. 16, No : 1, April 2019 , p-ISSN:1907-5243, e-ISSN: 2655-8416}

Untuk besarnya kuantitas pemesanan dengan menggunakan metode EOQ adalah 39 sack untuk jenis BOP, 58 sack untuk jenis BOPF, 58 sack untuk jenis PF, 35 sack untuk jenis DUST, 4 sack untuk jenis BP, 70 sack untuk jenis BT, 27 sack untuk jenis PF II, 19 sack untuk jenis DUST II, 4 sack untuk jenis BP II, 19 sack untuk jenis BT II, 8 sack untuk jenis DUST II, 39 sack untuk jenis FANN II, dan 8 sack untuk jenis DUST IV. Dari besar kuantitas pemesanan tersebut dapat dihitung total biaya yang dikeluarkan perusahaan jika menggunakan metode EOQ adalah sebesar Rp 414.195.905,-. Jumlah pemesanan dalam 1 periode (12 bulan) selanjutnya adalah sebanyak 77 kali pemesanan. Karena total biaya yang dikeluarkan perusahaan menggunakan metode EOQ lebih besar jika dibandingkan dengan total biaya yang dikeluarkan perusahaan selama ini maka dilakukan perhitungan selanjutnya menggunakan metode Lagrange.

\subsection{Analisis Metode Lagrange}

Metode Lagrange adalah metode yang digunakan untuk mengendalikan persediaan dengan kendala-kendala. Kendala yang ada yaitu biaya persediaan serta kapasitas gudang. Besar kuantitas pemesanan jika menggunakan metode Lagrange adalah 154 sack untuk jenis BOP, 195 sack untuk jenis BOPF, 182 sack untuk jenis PF, 131 sack untuk jenis DUST, 49 sack untuk jenis BP, 257 sack untuk jenis BT, 130 sack untuk jenis PF II, 101 sack untuk jenis DUST II, 51 sack untuk jenis BP II, 122 sack untuk jenis BT II, 67 sack untuk jenis DUST II, 181 sack untuk jenis FANN II, dan 68 sack untuk jenis DUST IV. Dari besar kuantitas pemesanan tersebut dapat dihitung total biaya yang dikeluarkan yaitu sebesar Rp 257.524.800,-. Frekuensi pemesanan dengan menggunakan metode Lagrange dalam 1 periode (12 bulan) selanjutnya adalah 25 kali pemesanan.

\subsection{Analisis Perbandingan Metode yang Digunakan Perusahaan dengan Metode Lagrange}

Perbandingan yang dilakukan adalah membandingkan kuantitas pemesanan serta total biaya persediaan dengan metode yang digunakan perusahaan selama ini dengan metode Lagrange. Besarnya kuantitas pemesanan dengan metode Lagrange tidak melebihi batas kapasitas gudang yang mencapai 5.000 sack.

Total biaya persediaan yang dikeluarkan perusahaan selama ini dengan metode yang digunakan perusahaan yaitu sebesar Rp 358.506.418,- sedangkan total biaya persediaan jika menggunakan metode Lagrange adalah sebesar Rp 257.524.800,- dengan frekuensi pemesanan sebanyak 25 kali pemesanan. Dari kedua total biaya persediaan tersebut dapat dilihat bahwa tedapat penurunan biaya dari metode yang digunakan perusahaan dengan metode Lagrange. Penurunan total biaya persediaan tersebut adalah sebesar Rp 127.981.619,- dengan persentase penurunan sebesar 33,2\%. Dengan penghematan tersebut perusahaan dapat meningkatkan keuntungan juga dari pengendalian persediaan dengan metode Lagrange.

\section{KESIMPULAN}

Berdasarkan penelitian yang dilakukan maka dapat disimpulkan sebagai berikut:

1. Jumlah safety stock yang harus disimpan pada gudang PT Perkebunan Nusantara VII Distrik Banyuasin adalah 8 sack, 12 sack, 2 sack, 7 sack, 1 sack, 14 sack, 6 sack, 4 sack, 1 sack, 4 sack, 2 sack, 8 sack, dan 2 sack untuk jenis BOP, BOPF, PF, DUST, BP, BT, PF II, DUST II, BP II, BT II, DUST III, FANN II, dan DUST IV secara berurutan. 


\section{Jurnal TEKNO}

(Civil Engineeering, Elektrical Engineeering and Industrial Engineeering)

Vol. 16, No : 1, April 2019 , p-ISSN:1907-5243, e-ISSN: 2655-8416

2. Jumlah produk yang harus dipesan untuk sekali pemesanan, yaitu 145 sack, 195 sack, 182 sack, 131 sack, 49 sack, 257 sack, 130 sack, 101 sack, 51 sack, 122 sack, 67 sack, 181 sack, dan 68 sack untuk jenis BOP, BOPF, PF, DUST, BP, BT, PF II, DUST II, BP II, BT II, DUST III, FANN II, dan DUST IV secara berurutan.

3. Dengan menggunakan metode Lagrange dapat menghemat biaya persediaan sebesar Rp 127.981.619,- dari total biaya yang selama ini dikeluarkan oleh perusahaan sebesar Rp 385.506.418,- dan biaya persediaan jika menggunakan metode Lagrange sebesar Rp 257.524.800,-. Biaya persediaan yang didapatkan dengan metode Lagrange lebih kecil dibandingkan dengan biaya persediaan yang dikeluarkan perusahaan dengan metode yang digunakan selama ini. Persentase penghematan dengan metode Lagrange adalah sebesar $33,2 \%$.

Saran yang dapat diberikan setelah melakukan penelitian ini adalah sebagai berikut:

1. Saran yang dapat diberikan kepada perusahaan adalah PT Perkebunan Nusantara Distrik Banyuasin dapat menerapkan metode Lagrange untuk mengendalikan persediaan teh pada gudang teh karena metode Lagrange dapat mengurangi biaya persediaan yang dikeluarkan untuk gudang teh tersebut.

2. Untuk peneliti selanjutnya dapat mempertimbangkan kendala yang tidak dipertimbangkan pada penelitian ini seperti elastisitas permintaan sehingga penelitian selanjutnya dapat menghasilkan hasil yang lebih baik

\section{DAFTAR PUSTAKA}

[1] Agustian, Hansel. 2015. Pengendalian Persediaan Suplemen Kesehatan Dengan Metode Economic Order Quantity (EOQ) Multi Item Di Stokis 339. Unika Musi Charitas, Palembang.

[2] Kusrini, Elisa. 2005. Sistem Persediaan Multi Item dengan Kendala Investasi dan Luas Gudang. Skripsi Jurusan Teknik Industri, Fakultas Teknologi Industri, Universitas Islam Indonesia. Yogyakarta.

[3] Ristono, Agus. 2008. Manajemen Persediaan. Cetakan Pertama. Graha Ilmu, Yogyakarta hal. 2-3.

[4] Nasution. 2008. Perencanaan dan Pengendalian Produk. Edisi Pertama. Graha Ilmu, Yogyakarta.

[5] Rangkuti, Freddy. 1998. Manajemen Persediaan: Aplikasi di Bidang Bisnis. PT Raja Graindo Persada, Jakarta hal. 10-11 dan 16-18.

[6] Tersine, Richard J. 1998. Principles Of Inventory And Materials Management. North Holland, Amerika.

[7] Makridakis, 1999. Metode dan Aplikasi Peramalan 1. Binarupa Aksara, Jakarta 